\title{
熱傷瘢痕後皮膚悪性腫瘍
}

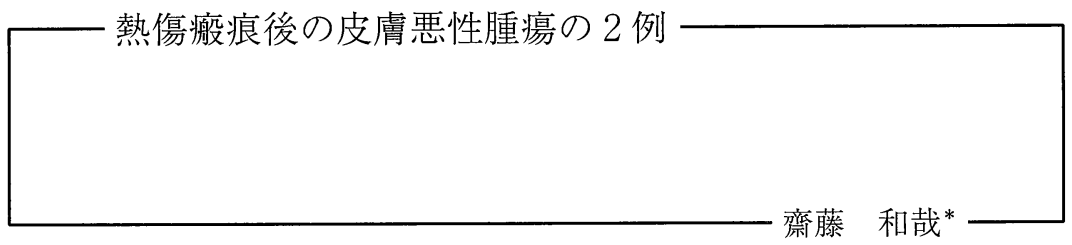

\section{Two Cases of Skin Cancer Arising On the Burn Scar}

Kazuya SAITOH *

* Department of Dermatology, Sapporo Social Security Hospital

The auther report two cases arising of skin cancer on the burn scar. A 72-year-old Japanese woman got burnt in the frontal scalp, when she was 3 years old. The tumor was an easiely bleeding nodule measuring $14 \times 14 \times 8 \mathrm{~mm}$ in size. Histological examination revealed a keratotic Basal Cell Carcinoma. Wide excision of the lesion and local skin flap were performed. Second case was an 86-year-old woman who had a burn on the left thigh during a neonatal period. It has grown up to the intractable ulceration in 1995 and it became hemorrhagic. The biopsy specimen showed that the ulcer is a squamous cell carcinoma. It was removed widely under the general anesthesia, and the skin graft was carried out in 1999. [Skin Cancer (Japan) 2001; 16 :233-236]

Key words : Burn scar, Basal cell carcinoma, Squamous cell carcinoma

はじめに

外傷, 機械的刺激, 紫外線, 種痘, 円盤状工 リテマトーデスなどの皮膚疾患および様々の瘏 痕が皮膚悪性腫瘍が発生母地や誘因 ${ }^{112)}$ となり うることは良く知られている。なかでも熱傷㓔 痕が皮膚悪性腫瘍の発生母地となった症例は多 数報告されている。今回, 熱傷㾿痕を発生母地 とした基底細胞癌および有棘細胞癌の 2 例を経 験したので報告する。

* 札幌厚生病院 皮膚科

\section{症例}

症例 $1: 72$ 歳, 女性

初診: 1999 年 3 月 29 日

主 訴：前頭部の腫瘤

家族歴：特記すべきことなし。

既往歴: 高血圧, 脳梗塞, 脳梗塞後後遺症

現病歴：3 歳時に前頭部に熱傷受傷。1995 年, 同部の腫瘤に気付き, 徐々に増大し, 易出血と なったため, 初診となった。

現 症：前頭部に暗赤色で $14 \times 14 \times 8 \mathrm{~mm} の$ 易出血性の腫瘤を認め(図 1), 生検施行した。

組織所見・病型：多数の囊腫様構造を有し, 腫瘍を構成する細胞は異型性を有する基底細胞 
様細胞で辺縁部では柵状配列を認め, 臨床型基 底細胞癌 (以下 $B C C$ ) 結節潰瘍型, 組織型 BCC 囊腫型と診断した（図 2a, b)。免疫組織化学染 色で変異型 $\mathrm{p} 53$ 蛋白は除性であった。

治 療：1999 年 5 月 12 日, 局所麻酔下で脂 肪層下層で切除（図 2c), 局所皮弁術施行した。 術後 1 年 10 力月現在, 再発抒よび転移を認めて いない。

症例 $2: 86$ 歳, 女性

初診: 1999 年 9 月 7 日

主 訴: 左大腿前面の潰晹

家族歴：特記すべきことなし。

既往歴：高血圧

現病歴：乳児期に左大腿にいらりにて熱傷受 傷した。1995 年に難治性潰犜出現に増大・易出 血となったため前医より紹介となり初診となった。

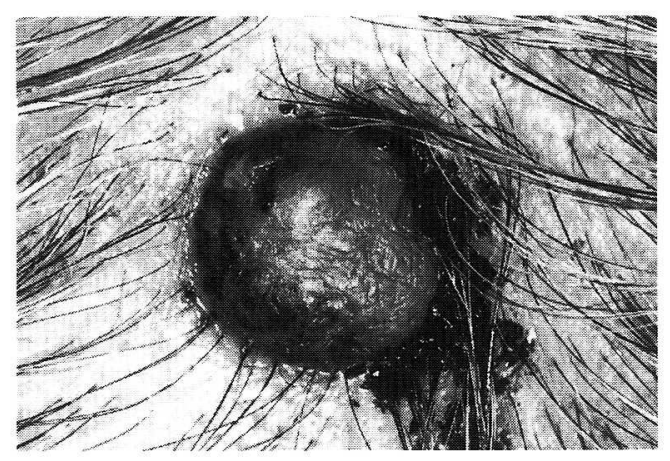

図1. 症例 1 初診時臨床

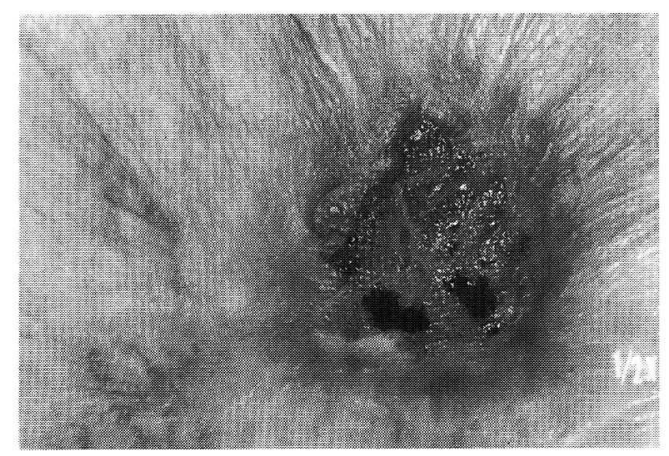

図 3. 症例 2 初診時臨床
現 症：左大腿部に紅色で $20 \times 18 \mathrm{~mm}$ の易出 血性の潰瘍を認めた（図 3)。

組織所見・病型：生検にて腫瘍細胞は好酸性 で異型性を有し一部に角質真珠を認めた（図 4 a,b)。Ga シンチ, CT, MRI，血清 SCC 抗体価 正常にて, 有棘細胞癌 (以下 SCC) 高分化型, T1NOM0, Stage I と診断した。免疫組織化学染

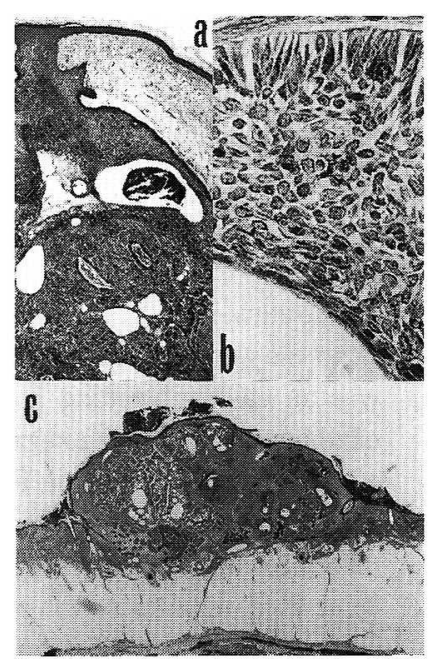

図 2. a,b 裹腫および柵状構造 c 病理組織全体像

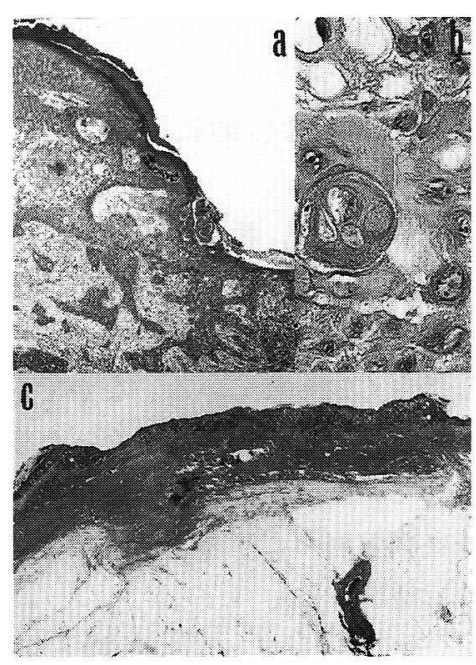

図 4.a 表皮より連なる腫瘍巣

b 好酸性で異型性を有する腫瘍細胞 一部に角質真珠

c 病理組織全体像 
色で変異型 p53 蛋白は陰性であった。

治 療：1999年 9 月 22 日, 全身麻酔下で辺 縁より $20 \mathrm{~mm}$ 以上離して筋膜上で切除（図 4 c), 植皮術施行した。術後 1 年 5 力月現在, 再 発および転移を認めていない。

\section{考案}

熱傷痒痕上に発生する皮膚悪性腫瘍として は, SCC が最も多く報告されているが，稀なが ら悪性線維性組織球腫 ${ }^{3)}$ や, 悪性黑色腫 ${ }^{4)} \mathrm{BCC}^{5)}$ 等の報告も見られる。加藤ら ${ }^{6)}$ は 1974 年以後 の本邦において統計的考察がなされた 258 例の 㿍痕性 SCC について集計しており，うち230例 が熱傷瘏痕癌である。これらと筆者が検索しえ た熱傷瘏痕上に生じた BCC の本邦報告例（表 1 ）とで比較したところ，年齢の不明な症例を 除き, 平均で初診時年齢は SCC で 55.3 歳, BCC で 62.2 歳, 受傷時年齢は SCC で 13.1 歳, BCC で 29.7 歳, 発症時年齢は SCC で 50.3 歳, BCC
で 50.3 歳, 受傷時年齢の不明でない症例におけ る発症までの平均期間は SCC で 37.2 年， BCC で 17.1 年であった。初診時年齢は BCC で 6.9 歳高く, 腫瘍の成長が遅いことや色素性母斑 · 黒子と誤認され受診が遅れることが理由と推測 された。発症年齢は両者とも約 50 歳でほぼ差は ないが，受傷時から発症までの期間は BCCが 20.1 年短かく，受傷年齢が高いほど癌発生まで の期間は短いとの報告と一致するものと考えら れた7)。BCC の好発年齢は 60 ～70 歳代である が ${ }^{8)}$, 熱傷瘏痕後の BCC では 50 歳代以下が 6 例を占め, 不明の 2 例を除いた 11 例で半数を超 えており発症年齢の低下が認められた。男女比 はSCCで 179:79，BCCで 9:4でほほ同率で 男性が69\%を占めていた。発症部位はSCCで下 肢 95 例 (42.8\%) で最も多く, BCC では躯幹 7 例 (53.8\%) で最多であった。

皮膚悪性腫瘍が熱傷痏痕上に発生する機序と して瘏痕部の真皮の線維化に慢性的に微小外傷 が加わりやすい。その外傷は血行の低下してい

表 1 . 本邦で報告された熱傷瘢痕上に発生した基底細胞癌

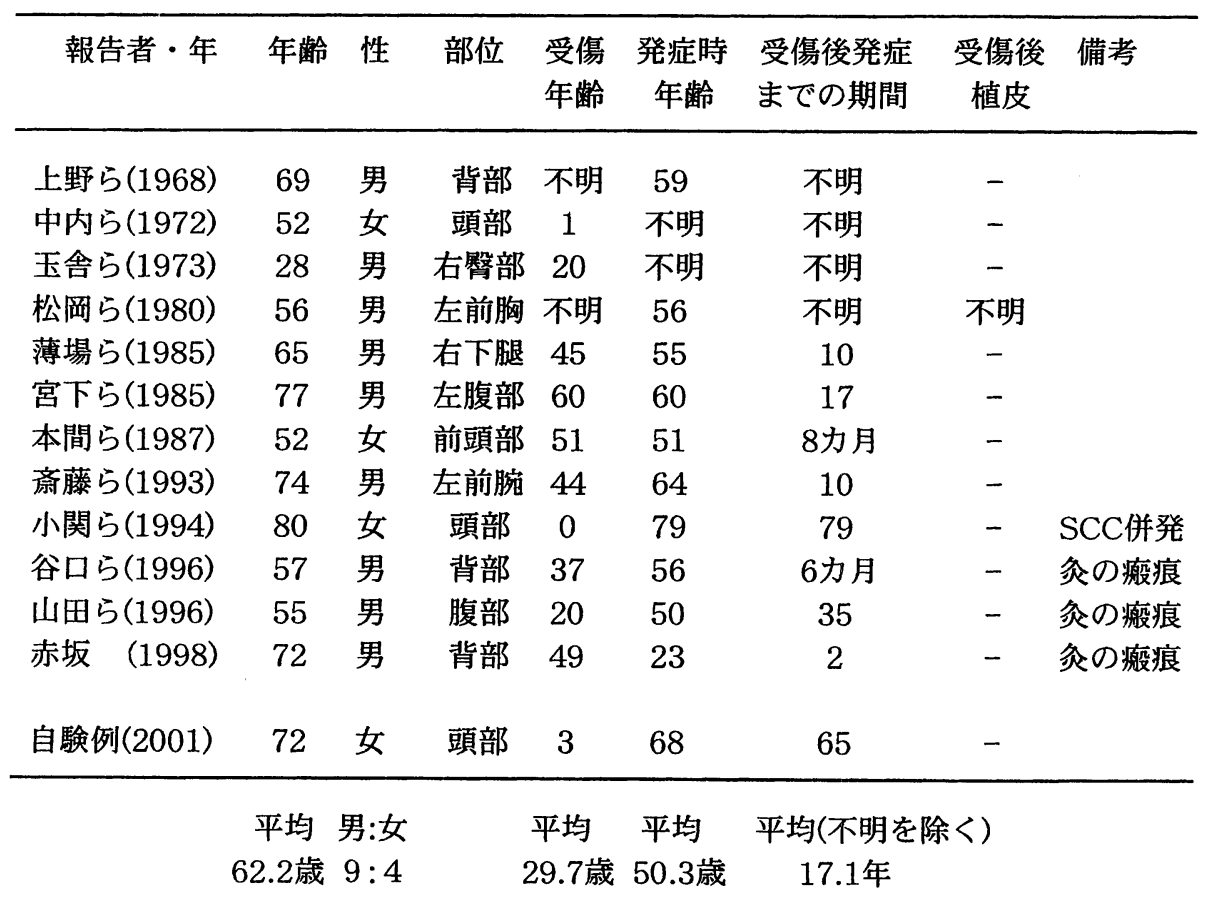


たるため治癒しにくいと考えられ ${ }^{9)}$ ，創傷治癒 は実験的にはプロモーター作用を有するとの報 告がある ${ }^{10)}$ 。浦野 ${ }^{11)}$ らは瘏痕皮膚の真皮では組 織学的に線維化, 付属器の消失, 脈管の減少等 がみられ正常皮膚と異なっており，特にリンパ 管の減少はリンパ球供給経路が低下し，腫瘍細 胞に対する免疫系の監視機構が有効に作用しな い可能性を示唆している。表1にあげた不明の1 例を除き全例受傷後植皮術を施行されていない ことより上記の機序が作用しているものではな いかと考えられた。

\section{文献}

1) 斎田俊明：2 . 有棘細胞癌 1) 有棘細胞癌の診断 と治療方針. Skin Cancer, 4:69-72, 1994.

2 ）小野友道: 3 . 基底細胞癌 1 ) 基底細胞癌の診断 と治療指針. Skin Cancer, 4:78-80, 1994.

3）宮川昌久, 福積聡, 大草康弘, 他：熱傷痒痕上に 発生した悪性線維性組織球腫の1例。臨皮, 51 ： 275-278, 1997.

4 ）齋藤和哉, 田中智, 山本美保, 他：熱傷瘏痕上に
発生した悪性黒色腫の 1 例. Skin Cancer, $7:$ 180183, 1992.

5）齋藤和哉, 浜岡秀爾, 森元洋介, 他 : 熱傷痏痕上 に生じた基底細胞上皮腫の 1 例。皮膚臨床，35： 143-147, 1993.

6）加藤直子, 安川香菜, 木村久美子: 瘕痕癌一国立 札幌病院皮膚科における 7 例の臨床的検討および 本邦の統計的報告 258 例のまとめ. Skin Cancer, $14: 164-171,1999$.

7) Lawrence, E.A.: Carcinoma arising in the scars of thermal burns. With special reference to the influence of the age at burn on the length of the induction period. Surg. Gynecol. Obstet., 95 : 579588, 1952.

8） 天津朗典, 前田晃, 荒金兆典, 他：当科に招ける 最近 5 年間の基底細胞上皮腫の組織分類: 既報告 集計例との比較. Skin Cancer, 14 : 302-307, 1999.

9) Treves, N. and Pack, G.T. : The development of cancer in burn scars. Surg. Gynec. Obstet., 51 : 749782, 1930.

10) Shubik, P.: Studies on the promoting phase in the stages of carcinogenesis in mice, rats, rabbits, and guinea pigs. Cancer, Res., 10:13-17, 1950.

11）浦野芳夫，久保宜明，荒瀬誠治：熱傷瘢痕と皮虐 癌. Molecular Medicine, 32: 1184-1189, 1995. 